\title{
Penugasan Pemerintah pada Badan Usaha Milik Negara Sektor Ketenagalistrikan Dalam Perspektif Hukum Korporasi
}

\author{
Muhammad Insa Ansari* \\ DOI: https://doi.org/10.22304/pjih.v4n3.a7
}

\begin{abstract}
Abstrak
Pemerintah akan mengeluarkan revisi Peraturan Pemerintah tentang Pendirian, Pengurusan, Pengawasan dan Pembubaran Badan Usaha Milik Negara. Melalui aturan ini pemerintah dapat memberikan penugasan khusus bagi BUMN. Fokus pembahasan artikel ini merupakan bidang ketenagalistrikan dan akan membahas mengenai penugasan apa saja yang diberikan oleh pemerintah kepada BUMN sektor ketenagalistrikan, selanjutnya, bagaimana penugasan pemerintah tersebut dalam perspektif hukum korporasi? Penulis berpendapat bahwa penugasan tersebut tidak sejalan dengan perspektif hukum korporasi. Penugasan pemerintah seharusnya diemban oleh BUMN dengan entitas perusahaan umum. Dalam praktik penugasan pemerintah diemban oleh perusahaan perseroan, padahal Undang-Undang Nomor 19 Tahun 2003 tentang BUMN secara tegas dibatasi entitas BUMN berdasarkan maksud dan tujuan, entitas Perum ditujukan untuk mengemban kemanfaatan dan entitas Persero untuk mencari keuntungan.
\end{abstract}

Kata kunci: BUMN, hukum korporasi, ketenagalistrikan, kewajiban pelayanan umum, penugasan pemerintah.

\section{Government Assignment on State-Owned Enterprise on Electricity Sector in Corporate Law Perspective}

\begin{abstract}
The Government will soon publish the revision of Ministerial Decree about Establishment, Arrangement, Supervision, and Dismission of State-owned and State-run Enterprises (SOES). Through this regulation, the government is able to implement special assignments towards SOEs. This article focuses on the field of electrical energy and will describe what kind of assignments that the government ordered to SOEs in electricity sector, and moreover how are the given assignments implied through the prespective of corporate law. The writer argues the special assignments given by the government are not in line with corporate law prespective. The assignments shall be conducted by SOEs under the entity of public companies. In practice, the government assignments are implemented by limited liability companies, even though according to the Law Number 19 Year 2003 about SOEs, it is wellsaid that SOEs' functions are limited based on specific purposes, whereas the public company entity is aimed to create advantages for public interests and limited liability company entity is aimed to create profits.
\end{abstract}

Keywords: SOEs, corporate law, electricity sector, public service obligation, assignment of government.

PADJADJARAN Jurnal IImu Hukum Volume 4 Nomor 3 Tahun 2017 [ISSN 2460-1543] [e-ISSN 2442-9325]

* Dosen Fakultas Hukum Universitas Syiah Kuala, Jln. Putroe Phang No. 1 Kopelma Darussalam, Banda Aceh, insa. ansari@unsyiah.ac.id, S.H. (Universitas Syiah Kuala), M.H. (Universitas Indonesia). Penulis sedang menempuh Pendidikan Doktor IImu Hukum pada Fakultas Hukum Universitas Indonesia. 


\section{A. Pendahuluan}

Pemerintah saat ini tengah merampungkan revisi Peraturan Pemerintah Nomor 45 Tahun 2005 tentang Pendirian, Pengurusan, Pengawasan dan Pembubaran Badan Usaha Milik Negara (PP 45/2005). ${ }^{1}$ Salah satu hal yang menjadi pembahasan adalah tentang penugasan bagi perusahaan Badan Usaha Milik Negara (BUMN). ${ }^{2}$ Deputi Bidang Infrastruktur Bisnis Kementerian BUMN Hambra mengatakan bahwa nantinya melalui aturan ini pemerintah dapat memberikan penugasan khusus bagi perusahaan BUMN. Penugasan ini juga dapat diberikan dalam keadaan yang mendesak sehingga sangat membutuhkan peran dari Kementerian BUMN. Hambra melanjutkan bahwa penugasan khusus ini akan kembali dibahas bersama jajaran kementerian terkait, termasuk di antaranya adalah Kementerian Keuangan dan jajaran kementerian teknis lainnya. Pembahasan tersebut juga akan membahas aturan tentang untung rugi perusahaan BUMN dalam menjalankan tugas khusus dari negara. ${ }^{3}$

Sebelumnya tanggal 24 November 2015 telah ada unggahan berita pada lama situs resmi Sekretariat Kabinet Republik Indonesia dengan judul: "BUMN Yang Dapat Penugasan Pemerintah Dapat Lakukan Penunjukan Langsung Anak Perusahaan."4 Dalam laman situs tersebut dinyatakan bahwa dalam pertimbangan mempercepat pelaksanaan program infrastruktur, pemerintah memandang perlu untuk melakukan perubahan kedua terhadap Peraturan Pemerintah Nomor 29 Tahun 2000 tentang Penyelenggaraan Jasa Konstruksi (PP 29/2000) sebagaimana telah diubah dengan Peraturan Pemerintah Nomor 59 Tahun 2010 tentang Perubahan atas PP 29/2000. Atas dasar pertimbangan tersebut maka pada tanggal 2 November 2015, Presiden Joko Widodo menandatangani Peraturan Pemerintah Nomor 79 Tahun 2015 tentang Perubahan Kedua atas PP 29/2000 tentang Penyelenggaraan Jasa Konstruksi (PP 79/2015). Perubahan PP 79/2015 ini menekankan bahwa pemilihan perencana konstruksi dan pengawas konstruksi dengan cara penunjukan langsung selain berlaku karena beberapa alasan (misalnya keadaan darurat, pekerjaan yang kompleks, pekerjaan yang perlu dirahasiakan, dan pekerjaan yang berskala kecil), juga berlaku untuk pekerjaan yang merupakan penugasan dari pemerintah kepada BUMN. ${ }^{5}$

Kedua pemberitaan di atas, baik pada laman media maupun situs resmi Sekretaris Kabinet Republik Indonesia menunjukan bahwa penugasan pemerintah pada BUMN semakin bertambah dan meningkat dari waktu ke waktu. Dalam Undang-Undang Nomor 19 Tahun 2003 tentang Badan Usaha Milik Negara (UU BUMN) sendiri pada

\footnotetext{
Dedy Afrianto, "Revisi Aturan, BUMN Siap-siap Terima Tugas Khusus Negara”, https://economy.okezone. com/read/2017/06/06/320/1708912/revisi-aturan-bumn-siap-siap-terima-tugas-khusus-negara, diunduh 22 September 2017.

Ibid.

Ibid.

Hubungan Masyarakat Sekretariat Kabinet Republik Indonesia, "BUMN Yang Dapat Penugasan Pemerintah Dapat Lakukan Penunjukan Langsung Anak Perusahaan", http://setkab.go.id/bumn-yang-dapat-penugasanpemerintah-dapat-lakukan-penunjukan-langsung-anak-perusahaan/, diunduh 23 September 2017.
}

5 Ibid. 
dasarnya sudah diatur penugasan pemerintah pada BUMN, yakni dalam Pasal 66 UU BUMN dinyatakan sebagaimana dikutip berikut ini:

“1) Pemerintah dapat memberikan penugasan khusus kepada BUMN untuk menyelenggarakan fungsi kemanfaatan umum dengan tetap memperhatikan maksud dan tujuan kegiatan BUMN.

2) Setiap penugasan sebagaimana dimaksud dalam ayat (1) harus terlebih dahulu mendapatkan persetujuan Rapat Umum Pemegang Saham (RUPS)/ Menteri."

Memperhatikan ketentuan Pasal 66 UU BUMN pada dasar penugasan khusus kepada BUMN telah mendapat landasan hukum dalam UU BUMN. Penjelasan atas Pasal 66 ayat (1) dan ayat (2) UU BUMN menyatakan:

“(1) Meskipun BUMN didirikan dengan maksud dan tujuan untuk mengejar keuntungan, tidak tertutup kemungkinan untuk hal-hal yang mendesak, BUMN diberikan penugasan khusus oleh pemerintah. Apabila penugasan tersebut menurut kajian secara finansial tidak fisibel, pemerintah harus memberikan kompensasi atas semua biaya yang telah dikeluarkan oleh BUMN tersebut termasuk margin yang diharapkan.

(2) Karena penugasan pada prinsipnya mengubah rencana kerja dan anggaran perusahaan yang telah ada, penugasan tersebut harus diketahui dan disetujui pula oleh RUPS/Menteri."

Pada tahun 2015, penugasan khusus kepada delapan BUMN untuk melayani kebutuhan publik (Public Service Obligation/PSO) yang direncanakan dalam Rancangan Anggaran Pendapatan dan Belanja Negara (RAPBN) 2016 memiliki jumlah biaya sebesar Rp201,3 triliun. ${ }^{6}$ Sekretaris Kementerian BUMN Imam Apriyanto Putro dalam Rapat Dengar Pendapat (RDP) Komisi VI Dewan Perwakilan Rakyat (DPR) lanjut memaparkan sebagai berikut:

“...depalan perusahaan yang mendapatkan alokasi PSO adalah PT Pertamina (Persero) sebesar Rp70,9 triliun, Perum Bulog Rp20,9 triliun, PT PLN (Persero) dianggarkan Rp50 triliun, Pupuk Indonesia Holding Company (PIHC) sekitar Rp30,06 triliun. Selanjutnya, Sang Hyang Seri dan Pertani (Persero) Rp1,023 triliun, PT KAI (Persero) Rp1,8 triliun, PT Pelni (Persero) Rp1,7 triliun, dan Perum LBKN Antara Rp138 miliar." $^{7}$

Sejalan dengan itu BUMN sektor ketenagalistrikan juga mengemban penugasan pemerintah dalam kewajiban pelayanan umum, ${ }^{8}$ maka pemerintah turut mempertahankan PT Perusahaan Listrik Negara (Persero) [PLN] sebagai perusahaan

Susan Silaban, “Delapan BUMN Kantongi PSO 2016 Rp201 Triliun”, http://www.imq21.com/news/ read/320049/20150903/171542/Delapan-BUMN-Kantongi-PSO-2016-Rp201-Triliun.html, diunduh 21 Februari 2016.

lbid.

8 Detik, "Pemerintah Pertahankan PLN Jadi Perusahaan PSO", http://finance.detik.com/ $\mathrm{read} / 2006 / 02 / 01 / 164533 / 530341 / 4 /$ pemerintah-pertahankan-pln-jadi-perusahaan-pso, diunduh 19 Februari 2016. 
negara yang menjalankan fungsi sosialnya atau pelaksana PSO. Penugasan pemerintah pada BUMN sektor ketenagalistrikan menimbulkan pro kontra terhadap kebijakan pemerintah tersebut. Salah satu pihak yang tidak setuju dengan pembebanan penugaan pemerintah adalah Rinaldy Dalimi, anggota Dewan Energi Nasional (DEN) yang menyatakan bahwa pengelolaan dan penyediaan kelistrikan oleh PLN selama ini tidak optimal. ${ }^{9}$ Menurut Dalimi, PLN sebagai perusahaan listrik milik negara tidak boleh rugi dalam hal bisnis namun juga dibebani tugas PSO berupa distribusi listrik bersubsidi, sehingga ia menyarankan adanya pembagian PLN ke dua perusahaan berbeda; satu perusahaan berperan murni menjalankan bisnis secara komersial dan satu perusahaan lain yang bertugas untuk menjalankan PSO. ${ }^{10}$

Sementara itu pada laman situs resmi Kementerian Energi dan Sumber Daya Mineral (ESDM) memperlihatkan kesetujuannya untuk pengembanan kewajiban pelayanan umum, sebagaimana dikutip berikut ini:

"Pada tahun 2011 PLN mencatat laba bersih (unaudited) sebesar Rp11 triliun, naik sebesar 16\% dibandingkan laba bersih 2010 yang sebesar Rp10,09 triliun. Laba ini terjadi karena PLN diberikan margin PSO oleh Pemerintah sebesar $8 \%$ pada tahun 2011. Pemberian margin ini dengan tujuan agar PLN memiliki fleksibilitas dalam mencari dana untuk keperluan investasi dalam rangka meningkatkan kapasitas pasokan dan memperluas jaringan listrik di Indonesia." ${ }^{11}$

Penugasan pemerintah pada BUMN sektor ketenagalistrikan merupakan kajian yang penting dilakukan terutama sekali dalam perspektif hukum korporasi. Sebelumnya Penulis telah memublikasikan artikel dengan judul: "BUMN dan Penguasaan Negara di Bidang Ketenagalistrikan" pada Jurnal Konstitusi, Vol. 14 No. 1, Maret 2017 yang diterbitkan oleh Kepaniteran dan Sekretaris Jenderal Mahkamah Konstitusi (MK). Dalam artikel tersebut diuraikan dan dianalisa 2 (dua) hal, yaitu: pertama, bagaimana BUMN dan penguasaan negara di bidang ketenagalistrikan dalam konstitusi dan peraturan perundang-undangan?; dan kedua, bagaimana pengaruh Putusan MK Perkara Nomor 111/PUU-XIII/2015 terhadap BUMN dan penguasaan negara di bidang ketenagalistrikan? Artikel tersebut membahas penguasaan negara. Namun demikian, penugasan pemerintah pada BUMN memiliki keterkaitan dengan penguasaan negara, maka hal yang membedakan artikel ini dengan artikel sebelumnya adalah artikel ini membahas penugasan pemerintah pada BUMN sektor ketenagalistrikan dalam perspektif hukum korporasi, yang mana entitas BUMN yang terdapat dalam UU BUMN dijadikan dasar untuk dilakukan analisa.

$9 \quad$ Estu Suryowati, “Pemerintah Disarankan Bentuk Satu Perusahaan Listrik Khusus Tangani PSO", http://ekonomi. kompas.com/read/2015/12/30/020700526/Pemerintah.Disarankan.Bentuk.Satu.Perusahaan.Listrik.Khusus. Tangani.PSO, diunduh 19 Februari 2016.

10 Ibid.

11 Kementerian Energi dan Sumber Daya Mineral, “Dengan Margin PSO 8\%, PLN Catat Laba Bersih Rp 11,7 Triliun”, http://www3.esdm.go.id/berita/39-listrik/5511-dengan-margin-pso-8-pln-catat-laba-bersih-rp-117-triliun. html?tmpl=component\&print=1\&page=, diunduh 25 November 2017 
Berdasarkan uraian di atas, maka dalam artikel ini akan dideskripsikan dan dianalisis dua hal, yaitu: pertama, penugasan apa saja yang diberikan oleh pemerintah kepada BUMN sektor ketenagalistrikan?; dan kedua, bagaimana penugasan pemerintah terhadap BUMN sektor ketenagalistrikan dalam perspektif hukum korporasi?

\section{B. Penugasan Pemerintah Pada Badan Usaha Milik Negara Sektor Ketenagalistrikan} Jimly Asshidiqqie dalam bukunya 'Gagasan Kedaulatan Rakyat Dalam Konstitusi dan Pelaksanaan di Indonesia' menyatakan bahwa pembatasan fungsi negara 'penjaga malam' berkembang dalam bidang politik dan juga ekonomi. ${ }^{12}$ Di bidang ekonomi pun turut berkembang paham 'laizzes faires', yakni paham yang mendalilkan bahwa negara harus membiarkan atau membebaskan warga untuk mengurus kepentingan ekonominya masing-masing agar kegiatan ekonomi dalam negara tersebut menjadi sehat. $^{13}$ Namun demikian, dalam perkembangan selanjutnya muncul gejala kapitalisme di lapangan perekonomian yang secara perlahan-lahan menimbulkan jurang kemiskinan yang sulit diselesaikan dengan tanggung jawab negara yang secara minimal dalam konsep negara 'jaga malam'. ${ }^{14}$ Jimly menjelaskan bahwa keadaan tersebut menghasilkan kesadaran baru terkait pentingnya keterlibatan negara dalam menangani serta mengatasi permasalahan yang bersangkutan, dengan demikian negara tidak lagi dapat melepaskan tanggung jawabnya dalam meningkatkan kesejahteraan masyarakat dan perlu ikut campur "agar sumbersumber kemakmuran tidak dikuasai oleh segelintir orang". ${ }^{15}$

Menurut Safri Nugraha dalam Pidato Pengukuhan Guru Besar Tetap pada Fakultas Hukum Universitas Indonesia tanggal 13 September 2006 dengan judul 'Hukum Administrasi Negara dan Good Governance', beliau memaparkan peranan pemerintah mengalami perubahan dari pengertian klasik government sebagai pemerintah telah bergeser menjadi pengertian governance sebagai kepemerintahan. $\mathrm{Hal}$ ini mengakibatkan perubahan kedudukan pemerintah yang tadinya merupakan penguasa tunggal di suatu negara menjadi pemerintah sebagai salah satu sektor di samping sektor swasta dan masyarakat sebagai mitra yang sejajar dalam kerangka governance. ${ }^{16}$ Jadi pengertian pemerintah sebagai 'government is to govern' dalam suatu negara pada saat ini telah bergeser ke paradigma baru tentang pemerintahan sebagai 'government is to serve people'. ${ }^{17}$ Pemerintah sebagai pelayan masyarakat harus memberikan pelayanan yang baik melalui regulasi yang diterbitkan dan melalui pelayanan jasa yang diberikan secara langsung kepada masyarakat. ${ }^{18}$ Pelayanan

12 Jimly Asshiddiqie, Gagasan Kedaulatan Rakyat Dalam Konstitusi dan Pelaksanaan di Indonesia, Jakarta: Ichtiar Baru Van Hoeve, 1994, hlm. 222.

Ibid.

Ibid.

Ibid.

16 Safri Nugraha, "Hukum Administrasi Negara dan Good Governance", Pidato Pengukuhan Guru Besar Tetap Fakutlas Hukum Universtias Indonesia, Depok-Indonesia, 13 September 2006, hlm. 2.

17 Ibid., hlm. 4.

18 M. Udin Silalahi, “Analisis Hukum Privatisasi BUMN (UU No. 19 Tahun 2003)”, Jurnal Hukum Bisnis, Vol. 26, No. 
yang diberikan pemerintah kepada masyarakat dilakukan dengan mempergunakan berbagai institusi pemerintahan termasuk institusi BUMN.

Perusahaan dengan modal milik negara yang ditanamkan di dalamnya merupakan suatu gejala universal dan hampir dikenal di semua negara. Umumnya perusahaan demikian dinamakan 'perusahaan negara' yang sekarang dikenal sebagai BUMN atau dalam kepustakaan dinamakan pula sebagai 'government enterprise' atau 'public enterprise'. ${ }^{19}$ Menurut Tjip Ismail, alinea ke-4 Pembukaan dan batang tubuh Undang-Undang Dasar Negara Republik Indonesia Tahun 1945 (UUD 1945) dan Pasal 33 sebagai konstitusi Negara Republik Indonesia merupakan dasar pijakan dan tujuan didirikan BUMN, sebagai salah satu pelaku ekonomi dalam perekonomian nasional berdasarkan demokrasi ekonomi. ${ }^{20}$

BUMN merupakan aset negara yang dapat memberikan kontribusi maksimal bagi kesejahteraan bangsa secara keseluruhan. ${ }^{21}$ Maksud dan tujuan pendirian BUMN berdasarkan Pasal 2 ayat (1) UU BUMN adalah: (a) memberikan sumbangan bagi perkembangan perekonomian nasional pada umumnya dan penerimaan negara pada khususnya; (b) mengejar keuntungan; (c) menyelenggarakan kemanfaatan umum berupa penyediaan barang dan/atau jasa yang bermutu tinggi dan memadai bagi pemenuhan hajat hidup orang banyak; (d) menjadi perintis kegiatan-kegiatan usaha yang belum dapat dilaksanakan oleh sektor swasta dan koperasi; dan (e) turut aktif memberikan bimbingan dan bantuan kepada pengusaha golongan ekonomi lemah, koperasi, dan masyarakat.

Menurut Ibrahim R., peranan BUMN tidak hanya sebatas pengelolaan sumber daya dan produksi barang yang meliputi hajat hidup orang banyak, tetapi juga berbagai kegiatan produksi dan pelayanan yang merupakan porsi swasta seperti untuk menjaga stabilitas ekonomi, monopoli atas sumber daya, dan kegiatan ekonomi tertentu yang berada di tangan negara. Negara memainkan peranan secara langsung dan tidak langsung dalam kehidupan ekonomi untuk menghindari dampak eksternal dan khusus dampak sampingan bagi lingkungan alam dan lingkungan sosial. Peran negara muncul dalam berbagai bentuk, misalnya: (1) stabilitas sistem ekonomi; dan (2) alokasi dan distribusi sumber daya, termasuk produk dan konsumsi. ${ }^{22}$

Sejalan dengan itu dewasa ini pemerintah memberikan penugasan-penugasan khusus kepada BUMN. Penugasan-penugasan khusus yang diberikan kepada BUMN sektor ketenagalistrikan diantaranya adalah sebagai berikut:

1, 2007, hlm. 21.

19 Rudhy Prasetya, Kedudukan Mandiri Perseroan Terbatas: Disertasi dengan Ulasan menurut Undang-Undang Nomor 1 Tahun 1995, Bandung: Citra Aditya Bakti, 1995, hlm. 90.

20 Tjip Ismail, "Peranan BUMN Dalam Penerimaan Pendapat Negara: Tinjauan dari Perspektif Pajak”, Jurnal Hukum Bisnis, Vol. 26, No. 1, 2007, hlm. 46.

21 Safri Nugraha, "Privatisasi BUMN, Antara Harapan dan Kenyataan”, Jurnal Hukum Bisnis, Vol. 26, No. 1, 2007, hlm. 17.

22 Ibrahim R., "Landasan Filosofis dan Yuridis Keberadaan BUMN: Sebuah Tinjauan”, Jurnal Hukum Bisnis, Vol. 26, No. 1,2007 , hlm. 5. 


\section{Penugasan Kepada Badan Usaha Milik Negara untuk Melakukan Percepatan Pembangunan Pembangkit Tenaga Listrik}

Pada tahun 2006 pemerintah memberikan penugasan kepada PLN (Persero) dengan Peraturan Presiden Nomor 71 Tahun 2006 tentang Penugasan kepada PT Perusahaan Listrik Negara (Persero) untuk Melakukan Percepatan Pembangunan Pembangkit Tenaga Listrik yang Menggunakan Batubara (Perpres 71/2006). Dalam Pasal 1 ayat (1) Perpres 71/2006 dinyatakan bahwa: "Pemerintah menugaskan kepada PT Perusahaan Listrik Negara (Persero), yang selanjutnya disebut PT PLN (Persero), untuk menyelenggarakan pengadaan pembangunan pembangkit tenaga listrik yang menggunakan batubara di lokasi dan dengan jadwal operasi proyek sebagaimana tercantum dalam Lampiran Peraturan Presiden ini".

Dalam Lampiran Perpres 71/2006, penugasan pemerintah kepada PLN (Persero) untuk melakukan percepatan pembangunan pembangkit tenaga listrik yang menggunakan batubara meliputi lokasi dalam daftar berikut ini:

\section{DAFTAR PROYEK PEMBANGKIT PLN}

PROYEK PEMBANGKIT PLN JAWA-BALI

\begin{tabular}{|c|c|c|c|c|c|c|c|}
\hline No & Lokasi Pembangkit & $\begin{array}{c}\text { Jumlah } \\
\text { Unit }\end{array}$ & $\begin{array}{c}\text { Kelas } \\
\text { Kapasitas } \\
\text { (MW) }\end{array}$ & No & Lokasi Pembangkit & $\begin{array}{c}\text { Jumlah } \\
\text { Unit }\end{array}$ & $\begin{array}{c}\text { Kelas } \\
\text { Kapasitas } \\
\text { (MW) }\end{array}$ \\
\hline 1 & PLTU 1 di Banten & 1 & 600 s.d 700 & 6 & PLTU 1 di Jateng & 3 & 300 s.d 400 \\
\hline 2 & PLTU 2 di Banten & 2 & 300 s.d 400 & 7 & PLTU 2 di Jateng & 1 & 600 s.d 700 \\
\hline 3 & PLTU 3 di Banten & 3 & 300 s.d 400 & 8 & PLTU 1 di Jatim & 2 & 300 s.d 400 \\
\hline 4 & PLTU 1 di Jabar & 3 & 300 s.d 400 & 9 & PLTU 2 di Jatim & 1 & 600 s.d 700 \\
\hline 5 & PLTU 2 di Jabar & 3 & 300 s.d 400 & 10 & PLTU 3 di Jatim & 2 & 300 s.d 400 \\
\hline
\end{tabular}

PROYEK PEMBANGKIT PLN LUAR JAWA-BALI

\begin{tabular}{|c|c|c|c|c|c|c|c|}
\hline No & Lokasi Pembangkit & $\begin{array}{c}\text { Jumlah } \\
\text { Unit }\end{array}$ & $\begin{array}{c}\text { Kelas } \\
\text { Kapasitas } \\
\text { (MW) }\end{array}$ & No & Lokasi Pembangkit & $\begin{array}{c}\text { Jumlah } \\
\text { Unit }\end{array}$ & $\begin{array}{c}\text { Kelas } \\
\text { Kapasitas } \\
\text { (MW) }\end{array}$ \\
\hline 1 & PLTU di NAD & 2 & 100 s.d 150 & 16 & PLTU 1 di Kalteng & 2 & 65 \\
\hline 2 & PLTU 1 di Sumut & 2 & 100 s.d 150 & 17 & PLTU 2 di Kalteng & 2 & 7 \\
\hline 3 & PLTU 2 di Sumut & 2 & 100 s.d 150 & 18 & PLTU 1 di Sulut & 2 & 25 \\
\hline 4 & PLTU di Sumbar & 2 & 100 s.d 150 & 19 & PLTU 2 di Sulut & 2 & 25 \\
\hline 5 & PLTU 1 di Babel & 2 & 10 & 20 & PLTU di Gorontalo & 2 & 25 \\
\hline 6 & PLTU 2 di Babel & 2 & 10 & 21 & PLTU di Sulsel & 2 & 50 \\
\hline 7 & PLTU 3 di Babel & 2 & 25 & 22 & PLTU di Sulteng & 2 & 10 \\
\hline 8 & PLTU 4 di Babel & 2 & 15 & 23 & PLTU 1 di NTB & 2 & 7 \\
\hline 9 & PLTU 1 di Riau & 2 & 7 & 24 & PLTU 2 di NTB & 2 & 25 \\
\hline 10 & PLTU 2 di Riau & 2 & 5 & 25 & PLTU 1 di NTB & 2 & 7 \\
\hline 11 & PLTU di Kepri & 2 & 7 & 26 & PLTU 2 di NTB & 2 & 15 \\
\hline 12 & PLTU di Lampung & 2 & 100 s.d 150 & 27 & PLTU di Maluku & 2 & 7 \\
\hline 13 & PLTU 1 di Kalbar & 2 & 25 & 28 & PLTU di Malut & 2 & 7 \\
\hline 14 & PLTU 2 di Kalbar & 2 & 50 & 29 & PLTU 1 di Papua & 2 & 7 \\
\hline 15 & PLTU 1 di Kalsel & 2 & 65 & 30 & PLTU 2 di Papua & 2 & 10 \\
\hline
\end{tabular}

Sumber: Diolah dari Lampiran Peraturan Presiden Nomor 71 Tahun 2006 
Perpres 71/2006 itu sendiri telah mengalami beberapa kali perubahan terakhir dengan Peraturan Presiden Nomor 193 Tahun 2014 tentang Perubahan Keempat atas Perpres 71/2006 tentang Penugasan Kepada PT Perusahaan Listrik Negara (Persero) Untuk Melakukan Percepatan Pembangunan Pembangkit Tenaga Listrik Yang Menggunakan Batubara (Perpres 193/2014). Berdasarkan Pasal 5 Perpres 193/2014, bahwa peraturan presiden tersebut berlaku sejak tanggal ditetapkan sampai dengan tanggal 31 Desember 2016.

Pada tanggal 8 Januari 2010 Presiden Susilo Bambang Yudhoyono menetapkan Peraturan Presiden Nomor 4 Tahun 2010 tentang Penugasan Kepada PT Perusahaan Listrik Negara (Persero) Untuk Melakukan Percepatan Pembangunan Pembangkit Tenaga Listrik Yang Menggunakan Energi Terbarukan, Batubara, dan Gas (Perpres 4/2010). Penugasan ini diberikan oleh pemerintah selama 4 (empat) tahun, hal ini sebagaimana dimaktub dalam Pasal 12 peraturan presiden sebagaimana dikutip berikut: "Peraturan Presiden ini mulai berlaku sejak tanggal ditetapkan sampai dengan tanggal 31 Desember 2014." Dengan peraturan presiden ini ditugaskan kepada BUMN sektor ketenagalistrikan untuk pembangunan tenaga listrik yang menggunakan energi terbarukan. Hal ini sebagaimana dinyatakan dalam Pasal 1 Perpres 4/2010 sebagai berikut:

"Pelaksanaan percepatan pembangunan pembangkit tenaga listrik yang menggunakan energi terbarukan, batubara, dan gas dilakukan melalui penugasan Pemerintah kepada PT PLN (Persero), yang selanjutnya disebut PT PLN (Persero) dan melalui kerja sama antara PT PLN (Persero) dan pengembang listrik swasta dengan skema jual beli tenaga listrik."

Penugasan yang dilakukan oleh pemerintah dalam hal ini mempergunakan dana yang bersumber dari Anggaran Pendapatan dan Belanja Negara (APBN). Hal ini sebagaimana dinyatakan dalam Pasal 5 Perpres 4/2010, sebagaimana dikutip berikut: "Pendanaan pembangunan pembangkit tenaga listrik dan transmisi terkait sebagaimana dimaksud dalam Pasal 3 berasal dari APBN, anggaran internal PT PLN (Persero), dan sumber dana lainnya yang sah sesuai dengan ketentuan peraturan perundang-undangan." Terkait dengan penugasan tersebut, maka berdasarkan Pasal 11 PLN menyampaikan laporan secara berkala sekali dalam 3 (tiga) bulan mengenai pelaksanaan pembangunan pembangkit tenaga listrik dan transmisi terkait sebagaimana dimaksud dalam Pasal 3 dan Pasal 6 kepada Tim Koordinasi Percepatan Pembangunan Pembangkit Tenaga Listrik yang dibentuk oleh pemerintah.

\section{Penugasan Kepada Badan Usaha Milik Negara Sektor Ketenagalistrikan untuk Melakukan Pembelian Tenaga Listrik dari Pembangkit Listrik Tenaga Panas Bumi}

Pada tanggal 16 Februari 2011 Menteri ESDM menetapkan Peraturan Menteri ESDM Nomor 2 Tahun 2011 tentang Penugasan Kepada PT Perusahaan Listrik Negara (Persero) Untuk Melakukan Pembelian Tenaga Listrik Dari Pembangkit Listrik 
Tenaga Panas Bumi dan Harga Patokan Pembelian Tenaga Listrik Oleh PT Perusahaan Listrik Negara (Persero) Dari Pembangkit Listrik Tenaga Panas Bumi. (Permen ESDM 2/2011).

Pasal 1 ayat (1) Permen EDSM 02/2011 dimaksud menyatakan sebagaimana dikutip berikut: "Dalam rangka memenuhi kebutuhan tenaga listrik di dalam wilayah usahanya dan penggunaan energi ramah lingkungan, menugaskan PT PLN (Persero) untuk membeli tenaga listrik dari pembangkit listrik tenaga panas bumi". Kemudian dalam Pasal 2 ayat (3) diatur bahwa dalam rangka penugasan sebagaimana dimaksud dalam Pasal 1 ayat (1) dan ayat (2) huruf a, PLN wajib membeli tenaga listrik yang berasal dari pembangkit listrik tenaga panas bumi sesuai dengan harga tenaga listrik hasil lelang Wilayah Kerja Pertambangan Panas Bumi. Permen ESDM 02/2011 merupakan salah satu peraturan menteri yang memberikan penugasan pemerintah pada BUMN sektor ketenagalistrikan.

\section{Penugasan Kepada Badan Usaha Milik Negara dalam Rangka Mempercepat Proses Pengadaan Tanah untuk Penyediaan Tenaga Listrik}

BUMN sektor ketenagalistrikan adakalanya mendapat penugasan khusus dari pemerintah dalam rangka mempercepat proses pengadaan tanah. Hal ini sebagaimana ditetapkan dalam Keputusan Menteri ESDM Nomor 2186K/91/ MEM/2014 tentang Penugasan Khusus Kepada PT Perusahaan Listrik Negara (Persero) Dalam Rangka Mempercepat Proses Pengadaan Tanah Untuk Penyedia Tenaga Listrik (Kepmen ESDM 2186K/2014).

Dalam konsideran Memutuskan, pada Diktum Kesatu Kepmen ESDM 2186K/2014, menyatakan sebagaimana dikutip berikut: "Menugaskan PT Perusahaan Listrik Negara (Persero) melakukan pengadaan tanah untuk kegiatan pembangunan infrastruktur ketenagalistrikan dalam rangka penyediaan tenaga listrik berupa pembangkit, gardu, jaringan transmisi dan jaringan distribusi tenaga listrik, serta sarana pendukungnya." Kemudian dalam Diktum Keempat dimaksud menyatakan bahwa: "Direksi PT Perusahaan Listrik Negara (Persero) wajib menyampaikan laporan mengenai pelaksanaan pengadaan tanah untuk kegiatan pembangunan infrastruktur ketenagalistrikan sebagaimana dimaksud pada Diktum Ketiga kepada Direktur Jenderal Ketenagalistrikan secara berkala setiap 6 (enam) bulan." Penetapan dalam Keputusan Menteri ESDM merupakan salah satu penugasan pemerintah pada BUMN sektor ketenagalistrikan.

\section{Penugasan Kepada Badan Usaha Milik Negara untuk Melakukan Kewajiban Pelayanan Umum (Public Service Obligation)}

Dalam praktik selama ini juga BUMN sektor ketenagalistrikan mengemban kewajiban pelayanan umum (PSO) dari negara. Padahal kewajiban pelayanan umum dari negara seyogyanya diemban oleh pemerintah selaku penyelenggara pemerintahan. Neal Ryan (et.al) menyatakan sebagaimana dikutip berikut:

"In theory, the public service works under the direction of minister 
and implements laws made by parliament. In practice, the role of the public service is much more complex than is implied by this theory. The public service has political, economic and social functions beyond its administrative role." 23

Namun PLN sebagai BUMN yang ditugaskan oleh pemerintah untuk menyediakan subsidi tenaga listrik.

Adapun nilai kewajiban pelayanan umum yang dibebankan kepada PLN dalam kurun 10 (sepuluh) tahun terakhir dan prediksi pada tahun 2016 dapat dilihat pada diagram berikut ini:

Nilai Kewajiban Pelayan Umum (Public Service Obligation) Yang Diemban PT Perusahaan Listrik Negara (Persero)

(dalam rupiah dan miliar)

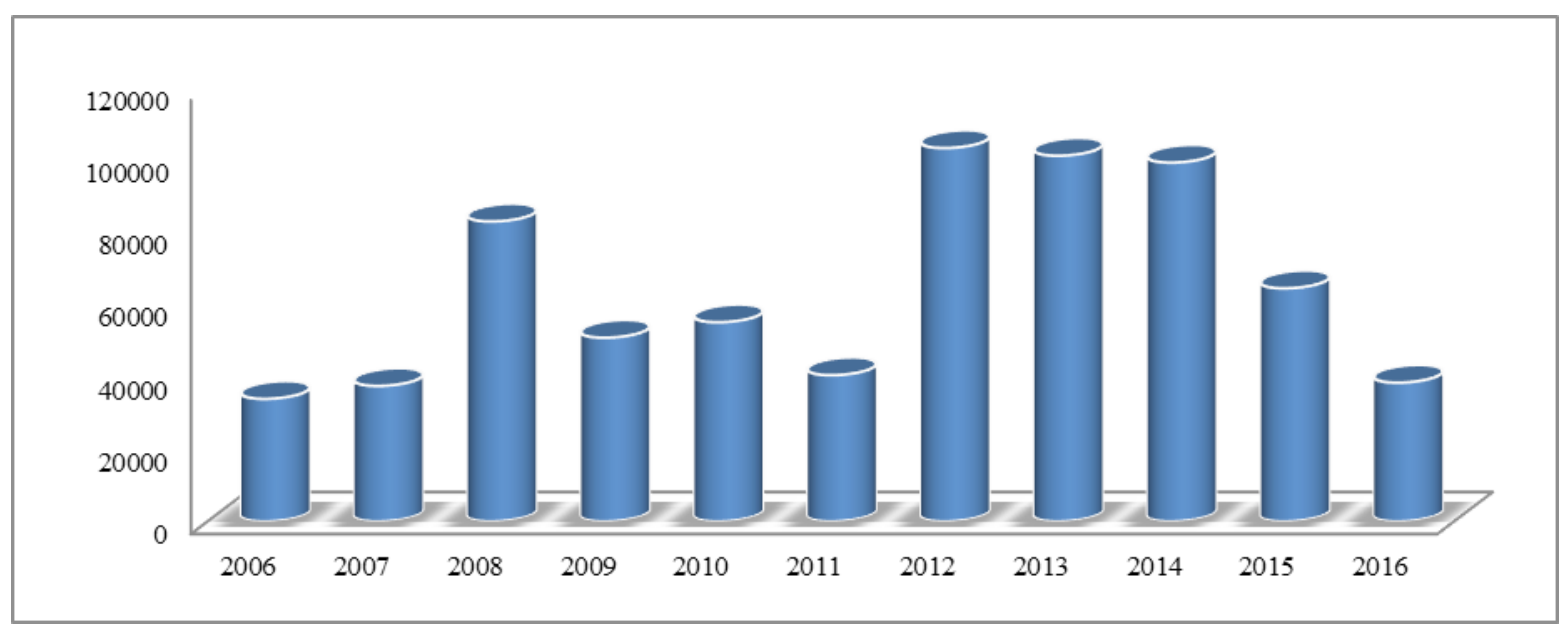

Sumber: Keasdepan Data dan Teknologi Informasi Kementerian BUMN.

Rincian nilai kewajiban pelayanan umum yang diemban oleh PLN adalah pada tahun 2006 sebesar 33.904,2 miliar rupiah, tahun 2007 sebesar 37.480,7 miliar rupiah, tahun 2008 sebesar 82.999,2 miliar rupiah, tahun 2009 sebesar 50.830,1 miliar rupiah, tahun 2010 sebesar 55.106,3 miliar rupiah, tahun 2011 sebesar 40.453,4 miliar rupiah, tahun 2012 sebesar 103.330 miliar rupiah, tahun 2013 sebesar 101.200 miliar rupiah, tahun 2014 sebesar 99.300 miliar rupiah, tahun 2015 sebesar 64.501,6 miliar rupiah dan proyeksi tahun 2016 sebesar 38.387,4 miliar rupiah. Data menunjukan bahwa nilai kewajiban pelayanan umum (PSO) yang diemban PLN (Persero) dalam kurun waktu tersebut relatif fluktuatif.

Berdasarkan uraian di atas menunjukkan bahwa BUMN sektor ketenagalistrikan menerima berbagai penugasan pemerintah, diantaranya berupa: (1) penugasan untuk melakukan percepatan pembangunan pembangkit tenaga listrik yang menggunakan batubara; (2) penugasan untuk melakukan pembelian tenaga listrik dari pembangkit listrik tenaga panas bumi; (3) penugasan pengadaan tanah untuk

23 Neal Ryan (et.al.), Government, Business and Society, Sydney: Pearson Education, 2003, hlm. 120. 
penyediaan tenaga listrik; dan (4) melakukan kewajiban pelayanan umum (PSO). Di samping itu banyak penugasan lainnya yang diberikan oleh pemerintah kepada BUMN sektor ketenagalistrikan yang tidak disebutkan dan diuraikan dalam artikel ini.

\section{Penugasan Pemerintah pada Badan Usaha Milik Negara Sektor Ketenagalistrikan dalam Perspektif Hukum Korporasi}

Penugasan pemerintah pada BUMN sektor ketenagalistrikan sebagaimana diuraikan pada bagian sebelumnya memiliki aneka ragam bentuk penugasannya. Penugasan pemerintah ini sendiri memiliki landasan yuridis baik dalam peraturan perundangundangan sektoral maupun peraturan perundang-undangan yang mengatur BUMN itu sendiri. Sebagai contoh kewajiban pelayanan umum yang diemban PLN didasarkan pada Pasal 66 UU BUMN. Pasal 66 UU BUMN menyatakan sebagaimana dikutip berikut ini:

“(1) Pemerintah dapat memberikan penugasan khusus kepada BUMN untuk menyelenggarakan fungsi kemanfaatan umum dengan tetap memperhatikan maksud dan tujuan kegiatan BUMN. (2) Setiap penugasan sebagaimana dimaksud dalam ayat (1) harus terlebih dahulu mendapatkan persetujuan RUPS/Menteri. ..."

Penugasan-penugasan dari pemerintah kepada BUMN sektor ketenagalistrikan dalam perspektif hukum korporasi dapat dikaji dan ditelaah dari berbagai sudut pandang, diantaranya adalah sebagaimana diuraikan berikut:

Pertama, penugasan pemerintah pada BUMN. Penugasan pada BUMN yang dilakukan pemerintah tidak terlepas dari kedudukan BUMN sebagai salah satu pelaku kegiatan ekonomi dalam perekonomian nasional berdasarkan demokrasi ekonomi di samping BUMN mempunyai peranan penting dalam penyelenggaraan perekonomian nasional guna mewujudkan kesejahteraan masyarakat. Di samping itu, penugasan pada BUMN itu mempunyai keterkaitan dengan maksud dan tujuan BUMN sebagaimana termatub dalam Pasal 2 ayat (1) UU BUMN.

Kedua, entitas BUMN. Entitas BUMN dapat dikaji dan ditelaah baik setelah berlaku UU BUMN maupun sebelum berlakunya UU BUMN. Setelah berlakunya UU BUMN entitas BUMN terdiri atas perusahaan umum dan perusahaan perseroan. Pengertian perusahaan umum berdasarkan Pasal 1 angka 4 UU BUMN adalah sebagaimana dikutip berikut:

"Perusahaan Umum, yang selanjutnya disebut Perum, adalah BUMN yang seluruh modalnya dimiliki negara dan tidak terbagi atas saham, yang bertujuan untuk kemanfaatan umum berupa penyediaan barang dan/atau jasa yang bermutu tinggi dan sekaligus mengejar keuntungan berdasarkan prinsip pengelolaan perusahaan."

Sementara itu perusahaan perseroan berdasarkan Pasal 1 angka 2 UU BUMN adalah sebagaimana dikutip berikut: 
"Perusahaan Perseroan, yang selanjutnya disebut Persero, adalah BUMN yang berbentuk perseroan terbatas yang modalnya terbagi dalam saham yang seluruh atau paling sedikit 51\% (lima puluh satu persen) sahamnya dimiliki oleh Negara Republik Indonesia yang tujuan utamanya mengejar keuntungan".

Di samping itu dalam Pasal 1 angka 3 UU BUMN terdapat entitas perusahaan perseroan terbuka, yakni: "Perusahaan Perseroan Terbuka, yang selanjutnya disebut Persero Terbuka, adalah Persero yang modal dan jumlah pemegang sahamnya memenuhi kriteria tertentu atau Persero yang melakukan penawaran umum sesuai dengan peraturan perundang-undangan di bidang pasar modal".

Perbedaan entitas perusahaan umum (Perum) dan perusahaan perseroan (Persero) berdasarkan pengertian yang terdapat dalam UU BUMN adalah: (1) dari segi modal, Perum seluruh modalnya dimiliki negara dan tidak terbagi atas saham, sementara Persero modalnya terbagi dalam saham yang seluruh atau paling sedikit 51\% (lima puluh satu persen) sahamnya dimiliki oleh Indonesia; (2) dari segi tujuan, Perum bertujuan untuk kemanfaatan umum berupa penyediaan barang dan/ atau jasa yang bermutu tinggi dan sekaligus mengejar keuntungan berdasarkan prinsip pengelolaan perusahaan, sementara Persero tujuan utamanya mengejar keuntungan.

Perbedaan entitas Perum dan Persero berdasarkan maksud dan tujuan entitas BUMN juga terdapat dalam UU BUMN. Maksud dan tujuan Persero berdasarkan Pasal 12 UU BUMN adalah: (a) menyediakan barang dan/atau jasa yang bermutu tinggi dan berdaya saing kuat; dan (b) mengejar keuntungan guna meningkatkan nilai perusahaan. Sementara maksud dan tujuan Perum berdasarkan Pasal 36 ayat (1) UU BUMN adalah: menyelenggarakan usaha yang bertujuan untuk kemanfaatan umum berupa penyediaan barang dan/atau jasa yang berkualitas dengan harga yang terjangkau oleh masyarakat berdasarkan prinsip pengelolaan perusahaan yang sehat.

Dari sisi pengertian, maksud, dan tujuan entitas Perum dan entitas Persero maka dapat dipahami bahwa entitas Perum lebih diperuntukkan untuk kemanfaatan umum (public utility), sementara entitas Persero diperuntukkan untuk mencari keuntungan (profit oriented). Penugasan pemerintah seyogyanya dibebankan pada BUMN dengan entitas Perum. Dalam praktiknya entitas Persero juga dipergunakan untuk penugasan pemerintah.

Sebelum berlakunya UU BUMN entitas BUMN terdiri atas perusahaan jawatan (Perjan), Perum, dan Persero. Adapun batasan dari ketiga entitas tersebut sebelum berlakunya UU BUMN adalah sebagai berikut:

1) Perjan: Entitas Perjan berakhir seiring dengan berlakunya UU BUMN. Hal ini sebagaimana dinyatakan dalam Pasal 93 ayat (1) UU BUMN sebagaimana dikutip berikut: "Dalam waktu 2 (dua) tahun terhitung sejak Undang-undang ini mulai berlaku, semua BUMN yang berbentuk Perusahaan Jawatan (Perjan), harus telah diubah bentuknya menjadi Perum atau Persero." Dalam Peraturan 
Pemerintah Nomor 6 Tahun 2000 tentang Perusahaan Jawatan (PP 6/2000), pada Pasal 1 angka 1 dinyatakan: "Perusahaan Jawatan adalah Badan Usaha Milik Negara sebagaimana diatur dalam Undang-Undang Nomor 9 Tahun 1969 dimana seluruh modalnya dimiliki oleh Pemerintah dan merupakan kekayaan Negara yang tidak dipisahkan serta tidak terbagi atas saham-saham." Adapun maksud dan tujuan Perjan berdasarkan Pasal 2 ayat (1) PP 6/2000 tersebut adalah "menyelenggarakan kegiatan usaha yang bertujuan untuk kemanfaatan masyarakat umum, berupa penyediaan jasa pelayanan yang bermutu tinggi dan tidak semata-mata mencari keuntungan".

2) Perum: Sebelum berlakunya UU BUMN, entitas Perum diatur dalam Peraturan Pemerintah Nomor 13 Tahun 1998 tentang Perum (PP 13/1998). Adapun pengertian Perum berdasarkan Pasal 1 angka 1 PP 13/1998 adalah "badan usaha milik Negara sebagaimana diatur dalam Undang-Undang Nomor 9 Tahun 1969 dimana seluruh modalnya dimiliki Negara berupa kekayaan negara yang dipisahkan dan tidak terbagi atas saham." Adapun maksud dan tujuan Perum berdasarkan Pasal 2 ayat (1) PP 13/1998 adalah "menyelenggarakan usaha yang bertujuan untuk kemanfaatan untuk berupa penyediaan barang dan atau jasa yang bermutu tinggi dan sekaligus memupuk keuntungan berdasarkan prinsip pengelolaan perusahaan".

3) Persero: Sebelum berlakunya UU BUMN, entitas perusahaan perseroan diatur dalam Peraturan Pemerintah Nomor 12 Tahun 1998 tentang Perusahaan Perseroan (PP 12/1998). Dalam Pasal 1 angka 2 PP 12/1998 dinyatakan sebagai berikut: "Perusahaan Perseroan adalah Badan Usaha Milik Negara yang dibentuk berdasarkan Undang-Undang Nomor 9 Tahun 1969 yang berbentuk Perseroan Terbatas sebagaimana dimaksud dalam Undang-Undang Nomor 1 Tahun 1995 yang seluruh atau paling sedikit $51 \%$ saham yang dikeluarkannya dimiliki oleh Negara melalui penyertaan modal secara langsung." Maksud dan tujuan persero berdasarkan Pasal 4 ayat (1) PP 12/1998 adalah: (a) menyediakan barang dan atau jasa yang bermutu tinggi dan berdaya saing kuat baik di pasar dalam negeri ataupun internasional; dan (b) memupuk keuntungan guna meningkatkan nilai perusahaan. Dalam Pasal 1 angka 3 PP 12/1998 juga terdapat pengertian Perusahaan Perseroan Terbuka, yakni: "Persero Terbuka adalah Persero yang modal dan jumlah pemegang sahamnya memenuhi kriteria tertentu atau Persero yang melakukan penawaran umum, sesuai dengan peraturan perundangundangan dibidang pasar modal".

Entitas Perjan, Perum, dan Persero sebelum berlaku UU BUMN berdasarkan peraturan pemerintah yang mengatur entitas-entitas tersebut, ketiga entitas tersebut mengacu pada Undang-Undang Nomor 9 Tahun 1969 tentang Penetapan Peraturan Pemerintah Pengganti Undang-Undang Nomor 1 Tahun 1969 tentang Bentuk-Bentuk Usaha Negara Menjadi Undang-Undang. Dalam undang-undang tersebut entitas-entitas BUMN didefinisikan sebagaimana termaktub dalam Pasal 2 sebagaimana dikutip berikut: 
"PERJAN adalah Perusahaan Negara yang didirikan dan diatur menurut ketentuan-ketentuan yang termaktub dalam Indonesische Bedrijvennwet (Stbl. 1927:419 sebagaimana yang telah beberapa kali diubah dan ditambah).

PERUM adalah Perusahaan Negara yang didirikan dan diatur berdasarkan ketentuan-ketentuan yang termaktub dalam UndangUndang No. 19 Prp Tahun 1960.

PERSERO adalah perusahaan dalam bentuk perseroan terbatas seperti diatur menurut ketentuan-ketentuan Kitab Undang-Undang Hukum Dagang (Stbl. 1847:23 sebagaimana yang telah beberapa kali diubah dan ditambah), baik yang saham-sahamnya untuk sebagiannya maupun seluruhnya dimiliki oleh Negara".

Secara singkat dapat dipahami bahwa entitas Perum baik pengaturan dalam UU BUMN maupun pengaturan sebelumnya lebih ditujukan untuk maksud dan tujuan kemanfaatan umum (public utility). Sementara itu entitas Persero baik dalam UU BUMN maupun pengaturan sebelumnya lebih ditujukan dengan maksud dan tujuan untuk mencari keuntungan (profit oriented).

Ketiga, sisi hukum korporasi. Setiap entitas dari BUMN sebagaimana diuraikan di atas memiliki maksud dan tujuan tersendiri. BUMN yang berbentuk perusahaan perseroan pada dasarnya adalah sebuah korporasi, sebuah badan usaha berbadan hukum yang bertujuan untuk mencari keuntungan. ${ }^{24}$ Dengan memahami makna dan konsekuansi badan hukum akan didapat pemahaman yang utuh tentang Perseroan. Ridwan Khairandy memaparkan bahwa korporasi sebagai badan hukum memiliki beberapa ciri substansif sebagai berikut: ${ }^{25}$

1) Terbatasnya tanggung jawab. Pada dasarnya para pendiri, pemegang saham, atau anggota suatu korporasi tidak bertanggung jawab secara pribadi terhadap kerugian atau utang korporasi. Jika badan usaha itu adalah Perseroan Terbatas, maka tanggung jawab pemegang saham hanya sebatas jumlah maksimum nominal saham yang ia kuasai dan tidak bertanggung jawab lebih dari itu.

2) Perpectual succesion. Sebagai sebuah korporasi yang ada atas haknya sendiri, perubahan keanggotaan tidak memiliki akibat atas status atau eksistensinya. Bahkan dalam Perseroan Terbatas, pemegang saham dapat mengalihkan saham yang ia miliki kepada pihak ketiga dan pengalihan tidak menimbulkan masalah kelangsungan perseroan yang bersangkutan. Jika Perseroan Terbatas yang bersangkutan adalah Perseroan Terbatas Terbuka dan sahamnya terdaftar di suatu bursa efek (listed), maka terdapat kebebasan untuk mengalihkan saham tersebut.

3) Memiliki kekayaan sendiri. Semua kekayaan yang dimiliki oleh badan itu sendiri, tidak oleh pemilik, anggota, atau pemegang saham adalah suatu kelebihan

\footnotetext{
24 Ridwan Khairandy, "Konsepsi Kekayaan Negara yang Dipisahkan dalam Perusahaan Perseroan", Jurnal Hukum Bisnis, Vol. 26, No.1, 2007, hlm. 32-33.

25 Ibid., hlm. 33.
} 
utama badan hukum. Dengan demikian, kepemilikan kekayaan tidak didasarkan pada anggota atau pemegang saham.

4) Memiliki kewenangan kontraktual serta dapat menuntut dan dituntut atas nama dirinya sendiri. Badan hukum sebagai subjek hukum diperlakukan seperti manusia yang memiliki kewenangan kontraktual. Badan itu dapat mengadakan hubungan kontraktual atas nama dirinya sendiri. Sebagai subjek hukum, badan hukum dapat dituntut dan menuntut di hadapan pengadilan.

Kelahiran Perseroan sebagai badan hukum (recht person, legal entity) karena dicipta atau diwujudkan melalui proses hukum (created by legal process) sesuai dengan ketentuan perundang-undangan. ${ }^{26}$ Menurut M. Yahya Harahap sebagaimana dikutip berikut:

"Perseroan sebagai makhluk atau subjek hukum artifisial disahkan oleh negara menjadi badan hukum memang tetap tidak bisa dilihat dan tidak dapat diraba (invicible and intangible). Akan tetapi, eksistensinya riil ada sebagai subjek hukum yang terpisah (separate) dan bebas (independent) dari pemiliknya atau pemegang sahamnya maupun dari pengurus dalam hal ini Direksi Perseroan."27

Selain itu, Perseroan secara terpisah dan independen melalui pengurus dapat melakukan perbuatan hukum (recht handeling, legal act) serta dapat menggugat atau digugat serta layaknya manusia (human being) selama jangka waktu berdirinya yang ditetapkan dalam Anggaran Dasar belum berakhir. ${ }^{28}$ Namun demikian, Perseroan tidak bisa dipenjarakan, melainkan dapat menjadi subjek perdata maupun tuntutan pidana dalam bentuk hukum 'denda'. ${ }^{29}$ Untuk itu penugasan pemerintah pada BUMN sektor ketenagalistrikan seyogyanya harus memperhatikan maksud dan tujuan dari entitas BUMN sebagaimana diatur dalam UU BUMN.

\section{Penutup}

Berdasarkan uraian pada bagian sebelumnya maka dapat disimpulkan sebagai berikut: Pertama, pemerintah memberikan sejumlah penugasan kepada BUMN sektor ketenagalistrikan, diantaranya berupa penugasan untuk melakukan percepatan pembangunan pembangkit tenaga listrik yang menggunakan batu bara, penugasan untuk melakukan pembelian tenaga listrik dari pembangkit listrik tenaga panas bumi, penugasan pengadaan tanah untuk penyediaan tenaga listrik; dan penugasan kewajiban pelayanan umum. Kedua, penugasan pemerintah terhadap BUMN sektor ketenagalistrikan tidak sejalan dengan perspektif hukum korporasi. Hal ini sebagaimana terlihat penugasan pemerintah seyogyanya diemban oleh BUMN dengan entitas Perum. Namun dalam praktik penugasan pemerintah pada BUMN diemban oleh Persero. Padahal dalam UU BUMN secara tegas dibatasi

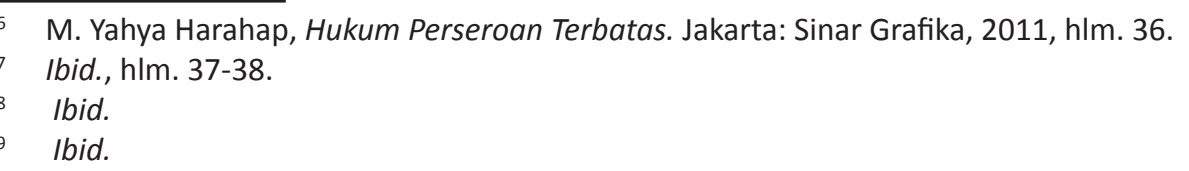


entitas BUMN berdasarkan maksud dan tujuan, bahwa entitas Perum ditujukan untuk mengemban kemanfaatan umum (public utility) dan entitas Persero ditujukan untuk mencari keuntungan (profit oriented).

Dari kesimpulan di atas, maka disarankan penugasan pemerintah perlu disesuaikan dengan hukum korporasi, yaitu memperhatikan maksud dan tujuan entitas BUMN. Hal ini dikarenakan setiap entitas BUMN memiliki maksud dan tujuan tersendiri sebagaimana diatur dalam peraturan perundang-undangan.

\section{Daftar Pustaka}

\section{Buku}

Jimly Asshiddiqie, Gagasan Kedaulatan Rakyat Dalam Konstitusi dan Pelaksanaan di Indonesia, Ichtiar Baru Van Hoeve, Jakarta, 1994.

M. Yahya Harahap, Hukum Perseroan Terbatas, Sinar Grafika, Jakarta, 2011.

Ryan, Neal (et.al.), Government, Business and Society, Pearson Education, Australia, 2003.

Rudhy Prasetya, Kedudukan Mandiri Perseroan Terbatas: Disertasi dengan Ulasan menurut Undang-Undang Nomor 1 Tahun 1995, Citra Aditya Bakti, Bandung, 1995.

\section{Dokumen Lain}

Dedy Afrianto, "Revisi Aturan, BUMN Siap-siap Terima Tugas Khusus Negara”, https:// economy.okezone.com/read/2017/06/06/320/1708912/revisi-aturan-bumnsiap-siap-terima-tugas-khusus-negara, diunduh 22 September 2017.

Kementerian Energi dan Sumber Daya Mineral, "Dengan Margin PSO 8\%, PLN Catat Laba Bersih Rp 11,7 Triliun", http://www3.esdm.go.id/berita/39listrik/5511-dengan-margin-pso-8-pln-catat-laba-bersih-rp-117-triliun. html?tmpl=component\&print=1\&page=, diunduh 25 November 2017.

Detik, "Pemerintah Pertahankan PLN Jadi Perusahaan PSO", http://finance.detik. com/read/2006/02/01/164533/530341/4/pemerintah-pertahankan-pln-jadiperusahaan-pso, diunduh 19 Februari 2016.

Estu Suryowati, "PemerintahDisarankan BentukSatuPerusahaan ListrikKhususTangani PSO", $\quad$ http://bisniskeuangan.kompas.com/read/2015/12/30/020700526/ Pemerintah.Disarankan.Bentuk.Satu.Perusahaan.Listrik.Khusus.Tangani.PSO, diunduh 19 Februari 2016.

Hubungan Masyarakat Sekretariat Kabinet Republik Indonesia, "BUMN Yang Dapat Penugasan Pemerintah Dapat Lakukan Penunjukan Langsung Anak Perusahaan", http://setkab.go.id/bumn-yang-dapat-penugasan-pemerintah-dapat-lakukanpenunjukan-langsung-anak-perusahaan/, diunduh 23 September 2017.

Ibrahim R., "Landasan Filosofis dan Yuridis Keberadaan BUMN: Sebuah Tinjauan", Jurnal Hukum Bisnis, Vol. 26, No. 1, 2007.

M. Udin Silalahi, “Analisis Hukum Privatisasi BUMN (UU No. 19 Tahun 2003)”, Jurnal Hukum Bisnis, Vol. 26, No. 1, 2007. Ridwan Khairandy, "Konsepsi Kekayaan 
Negara yang Dipisahkan dalam Perusahaan Perseroan", Jurnal Hukum Bisnis, Volume 26, Nomor 1, 2007.

Safri Nugraha, "Hukum Administrasi Negara dan Good Governance", Pidato Pengukuhan Guru Besar Tetap Fakultas Hukum Universitas Indonesia, DepokIndonesia, 13 September 2006.

"Privatisasi BUMN, Antara Harapan dan Kenyataan", Jurnal Hukum

Bisnis, Volume 26, Nomor 1, 2007.

Susan Silaban, "Delapan BUMN Kantongi PSO 2016 Rp201 Triliun", http://www. imq21.com/news/print/320049/20150903/171542/Delapan-BUMN-KantongiPSO-2016-Rp201-Triliun.html, diunduh 21 Februari 2016.

Tjip Ismail, "Peranan BUMN Dalam Penerimaan Pendapat Negara: Tinjauan dari Perspektif Pajak", Jurnal Hukum Bisnis, Vol. 26, No. 1, 2007.

\section{Dokumen Hukum}

Undang-Undang Dasar Negara Republik Indonesia Tahun 1945.

Undang-Undang Nomor 19 Tahun 2003 tentang Badan Usaha Milik Negara.

Peraturan Pemerintah Nomor 12 Tahun 1998 tentang Perusahaan Perseroan.

Peraturan Pemerintah Nomor 13 Tahun 1998 tentang Perusahaan Umum.

Peraturan Pemerintah Nomor 6 Tahun 2000 tentang Perusahaan Jawatan.

Peraturan Pemerintah Nomor 29 Tahun 2000 tentang Penyelenggaraan Jasa Konstruksi.

Peraturan Pemerintah Nomor 45 Tahun 2005 tentang Pendirian, Pengurusan, Pengawasan dan Pembubaran Badan Usaha Milik Negara.

Peraturan Pemerintah Nomor 79 Tahun 2015 tentang Perubahan Kedua atas

Peraturan Pemerintah Nomor 29 Tahun 2000 tentang Penyelenggaraan Jasa Konstruksi.

Peraturan Presiden Nomor 4 Tahun 2010 tentang Penugasan Kepada PT Perusahaan Listrik Negara (Persero) Untuk Melakukan Percepatan Pembangunan Pembangkit Tenaga Listrik Yang Menggunakan Energi Terbarukan, Batubara, dan Gas.

Peraturan Presiden Nomor 71 Tahun 2006 tentang Penugasan Kepada PT Perusahaan Listrik Negara (Persero) Untuk Melakukan Percepatan Pembangunan Pembangkit Tenaga Listrik Yang Menggunakan Batubara.

Peraturan Presiden Nomor 193 Tahun 2014 tentang Perubahan Keempat atas Peraturan Presiden Nomor 71 Tahun 2006 tentang Penugasan Kepada PT Perusahaan Listrik Negara (Persero) Untuk Melakukan Percepatan Pembangunan Pembangkit Tenaga Listrik Yang Menggunakan Batubara.

Peraturan Menteri Energi dan Sumber Daya Mineral Nomor 2 Tahun 2011 tentang Penugasan Kepada PT Perusahaan Listrik Negara (Persero) Untuk Melakukan Pembelian Tenaga Listrik Dari Pembangkit Listrik Tenaga Panas Bumi dan Harga Patokan Pembelian Tenaga Listrik Oleh PT Perusahaan Listrik Negara (Persero) Dari Pembangkit Listrik Tenaga Panas Bumi. 
Keputusan Menteri Energi dan Sumber Daya Mineral Nomor 2186K/91/MEM/2014 tentang Penugasan Khusus Kepada PT Perusahaan Listrik Negara (Persero) Dalam Rangka Mempercepat Proses Pengadaan Tanah Untuk Penyedia Tenaga Listrik. 